\title{
Avengers of Bleiburg: Émigré Politics, Discourses of Victimhood and Radical Separatism during the Cold War
}

\author{
MATE NIKOLA TOKIĆ \\ Central European University
}

\begin{abstract}
Summary
Bleiburg was at the center of a deeply-ingrained national victim-complex that served as an integral component of post-war Croatian émigré identity discourse. This article explores the relationship between this victim-complex and the radicalization of a small but active group of Croatian émigrés in the 1960s. It examines how discourses regarding "Serbo-communist" genocide first at Bleiburg and later within socialist Yugoslavia both radicalized many young emigrants to the West and was used to justify acts of terrorism against the regime in Belgrade. More specifically, the article explores how disputes within the émigré community itself concerning responsibility for Bleiburg contributed to the radicalization process. While not the only factor leading to an embrace of political violence by younger radicals, this generational schism surrounding the memory politics of Bleiburg proved central to the development of a campaign of émigré separatists terrorism aimed at the hated Yugoslav state that lasted more than two decades.
\end{abstract}

Keywords: Political Violence, Radicalization, Separatism, Generational Conflict, Émigrés

\section{Introduction}

In the early morning hours of 20 June, 1972, nineteen heavily armed men illegally crossed the border into socialist Yugoslavia from neighboring Austria. Notably, given the subject of this special issue, they crossed near the Slovenian town of Dravograd which sits seventeen kilometers - or just over ten miles - from the town of Bleiburg. The majority of the men were Croatian emigrants living in Australia, nearly half of whom had in fact become naturalized citizens of their new country. They were also all members of the Croatian Revolutionary Brotherhood 
(HRB - Hrvatsko revolucionarno bratstvo), a radical Croatian separatist organization formed in a suburb of Sydney in the summer of 1961 whose aim was the establishment - or rather, re-establishment - of an independent Croatian state. ${ }^{1}$ In its first ten years of existence, the HRB had proven to be one of the most extreme separatist organizations in the Croatian emigration, responsible for a number of acts of political violence, including but not limited to a previous failed armed incursion into socialist Yugoslavia in 1963, bombs at a cinema and at the main train station in Belgrade in 1968 and the assassination of a Yugoslav diplomat in West Germany in 1967.

The men had entered socialist Yugoslavia with the aim of inciting a popular Croatian uprising against - in their words - the "Serbo-communist" regime in Belgrade. Just months before, in December 1971, the Yugoslav government had brought to an abrupt and punitive end a campaign for greater national liberalization within the Socialist Republic of Croatia known varyingly as the Croatian Spring (Hrvatsko proljeće) or maspok (masovni pokret or "mass movement"). Central to maspok was a call - including by many within the League of Communists of Croatia - for greater decentralization of the federal Yugoslav state and an increase in political, economic and cultural autonomy for the republic. Tito's ultimate response was a crack-down against supporters of the Croatian Spring and a purging of Croatia's Party leadership (Irvine, 2008). For the HRB, both the nationalist impetus behind the Croatian Spring and the manifestly severe response by Tito and the Party leadership in Belgrade were not just indications but indeed proof that the Croatian nation was ripe for revolution. All that was needed was a spark to ignite the powderkeg that was the Croatian nation's will to free itself from the fetters of Belgrade. Operacija Feniks (Operation Phoenix), as the incursion of the nineteen men was codenamed by the HRB, would be just that.

With the benefit of hindsight, it is easy to see that Feniks was, at best, a misguided adventure. Within five weeks of entering socialist Yugoslavia, the incursion was in shambles; fifteen of the guerillas were dead, the remaining four were in the custody of Yugoslav authorities, and the prospects for an armed Croat insurrection against the regime in Belgrade remained as remote as ever. The whole escapade was so incongruent to locals in and around the central Bosnian town of Bugojno where the would-be revolutionaries had amassed, in fact, that many believed the guerillas to be actors in the shooting of a film about Second World War-era Partisans (Borne, 1972). This said, operation Feniks was not the unmitigated calamity that the HRB's

${ }^{1}$ For a detailed security services report on the HRB, see: Parliament of the Commonwealth of Australia (Hereafter PCA)-Senate. Tabled Papers, 27 March 1973: "Croatian Extremists". Appendix A.7, Doc: "Commonwealth Police Crime Intelligence: The Croatian Revolutionary Brotherhood. Hrvatska [sic] Revolucionarno Bratstvo". 
previous incursion of 1963 - dubbed Operation Kangaroo - had been. ${ }^{2}$ Feniks was quashed only following the largest mobilization of Yugoslavia's Territorial Defense forces (TO - Teritorijalna obrana), in the history of socialist Yugoslavia, and had resulted in the death of thirteen soldiers and the wounding of an additional fourteen. Such was the seriousness with which the government in Belgrade took the incursion and its repercussions that a CIA report written just two months following the capture of the last guerilla noted, "the Yugoslav government is treating the issue [meaning both operation Feniks specifically and émigré Croatia separatism generally] as if it involved a threat to the regime and to the survival of the federal state" ("Yugoslavia...", 2007: 470).

Even if only perhaps a peripheral detail, one of the more interesting footnotes to the story about the Bugojno Group (Bugojanska skupina) - as the paramilitaries have come to be known - concerns the guerilla handbook used in the preparation for and strategy behind the incursion. Written by the commander of operation Feniks, Adolf Andrić, the manual was entitled Avengers of Bleiburg: "Handbook" for the Guidance of Croatian Guerillas (Osvetnici Bleiburga: "Priručnik" za vođenje Hrvatske gerile) (Apostol Plemić, 1974). Avengers of Bleiburg was modelled on the influential revolutionary pamphlet 150 Questions for a Guerilla written by General Alberto Bayo, a Cuban veteran of the Spanish Civil War and the man tasked with training Fidel Castro's revolutionary army - including Che Guevera - in guerilla combat in the lead-up to the overthrow of the Batista regime (Bayo, 1963). Andrić - who wrote under the pseudonym Apostol Plemić - does not directly acknowledge his debt to Bayo, but he does cite the latter in a passage in which he makes the claim that the Cuban revolution represents "the best example of how an emigration can initiate a revolution in their own country" (Apostol Plemić, 1974: 29). In Avengers of Bleiburg, Andrić reduces the number of questions (and answers) to sixty from Bayo's original one hundred and fifty. He also adapts the text to the specifics of Croatian separatist politics and the strategic and technical particulars of guerilla warfare in and against socialist Yugoslavia. In both form and content, however, Andrić's text follows closely the one written by the tactician behind the - importantly - successful Cuban revolution.

On the matter of Bleiburg itself - perhaps not terribly unexpectedly - Andrić's handbook actually has little to say. First and foremost, simply, Avengers of Bleiburg was a manual for action. The majority of the text is dedicated to developing the diverse expertise necessary to wage successful guerilla warfare, including although

${ }^{2}$ For a secret service analysis of Operation Kangaroo, see: PCA-Senate. Tabled Papers, 27 March 1973: "Croatian Extremists". Appendix A.5, Doc: “The Croatian Revolutionary Brotherhood'; Hrvatsko Revolucionarno Bratstvo - H.R.B. (Position Paper as at $1^{\text {st }}$ May, 1967)”, p. 11-12. 
certainly not limited to sabotage, infiltration, diversionary tactics, bomb-making, paramilitary structure and the production and dissemination of propaganda. Secondly, and directly related to the first point, the intended audience of the handbook were those already deeply involved in the radical separatist movement, if not those in fact long committed to the violent revolutionary overthrow of the hated Yugoslav state. The "tragedy of Bleiburg" would not only have been eminently familiar to readers of Avengers of Bleiburg, it may have been a principal motivating factor leading to their radicalization. Both the pictures of and hand-drawn homage to the " 300,000 Croatian graves of Bleiburg"3 found on page 3 , for instance, would have needed no further explanation, exposition or even comment. Neither would the avowal later in the text that the Yugoslav communists leader Milovan Đilas' words: "The Croatian army should die, such that Yugoslavia may harken to live' still rings in the ears of Croatian revolutionaries, mixed together with the death cries of the $[500,000]$ weakened Croatian men, women and children from the fields of Bleiburg and the Way of the Cross" (ibid.: 34). ${ }^{4}$ For the already radicalized readership of Avengers of Bleiburg, broadly speaking, Andrić's declaration that "The cry for vengeance and justice [for the victims of Bleiburg] is that which nourishes the future Croatian assassin" (ibid.) would have presented itself as a truism rather than a revelation.

What is a revelation, however - albeit one perhaps not immediately obvious - is who Andrić actually declares capable of avenging Bleiburg. Andrić begins the concluding remarks to his text with the declaration, "This manual is intended solely for those Croats who wish to make of themselves modern Croatian revolutionaries. Modern Croatian revolutionaries are the only possible AVENGERS OF BLEIBURG" (ibid.: 137). On the surface, the statement does not strike the contemporary reader as especially unexpected or noteworthy, no less particularly barbed or even incendiary. The inclusion - and indeed repetition - of the adjective "modern" when describing the "only possible" type of Croatian revolutionary able to redress the great tragedy that had befallen the Croat nation, however, was meant to draw a clear line between two competing generations of post-war emigrants. The first was those who had fled socialist Yugoslavia in the immediate aftermath of the Second World War. The second was a wave of semi-émigré Croats either too young to have

3 Notably, 300,000 is prominently written twice in the drawing.

4 The number 500,000 appears in the sentence preceding the one quoted. It should be noted that within thirty-one pages, the number of victims at Bleiburg has risen by 200,000 . Whether 300,000 or 500,000 , the number of victims is greatly exaggerated. Although exact figures are impossible to determine, impartial estimates put the number killed at 70,000 to 80,000. For a discussion of the debate surrounding the number of victims, see Martina Grahek Ravančić's article in this special issue. 
been directly involved in the war or, in many cases, were even born after the war's conclusion, who started to emigrate in large numbers from socialist Yugoslavia to the West starting in the late 1950s and early 1960s. Andrić and the eighteen other members of the Bugojno group, to leave no doubt, all belonged to the latter, younger generation. ${ }^{5}$

A conflict between the two generations of anti-Yugoslav emigrants was not just a defining feature of émigré Croat separatism during the Cold War. It was central to the return to violence in the struggle for national independence from Belgrade beginning in the early 1960s. For just over two decades - from 1962 to 1983 - radical Croat separatists ranked globally amongst the most active perpetrators of terrorism and political violence. This violence began on 29 November, 1962, when twentysix members of a group called the Croatian Crusaders Brotherhood (HKB $-\mathrm{Hr}$ vatsko križarsko bratstvo) stormed the Yugoslav Trade Mission in the Bad Godesberg neighborhood of the West German capital Bonn, destroying the building and killing the Mission's Serbian porter (Clarkson, 2013: 65-71). ${ }^{6}$ In the decade that followed, security officials blamed Croatian separatists for at least fifty-two significant incidents of terrorism during one ten-year period in Australia alone. ${ }^{7}$ Globally, according to one estimation, radical Croat émigrés were responsible for more than fifty assassinations or assassination attempts, forty public bombings, and two airplane hijackings in the northern hemisphere during the same period (Clissold, 1979: 10). Such was the seriousness of Croatian émigré terrorism that the West German government declared émigré Croatian separatism to be "the Number One problem with foreigners" in the country, ${ }^{8}$ while the American FBI classified Croats together with the Puerto Rican Armed Forces of National Liberation (FALN - Fuerzas Armadas de Liberación Nacional) and the Cuban Omega 7 as the most active

5 The average age of those involved in operation Feniks was twenty-eight, with the oldest being thirty-nine and the youngest just nineteen. Andric himself was only thirty at the time of the incursion. Expressed differently, just two members of the Bugojno group were born before the Second World War started, while nearly half were born in the year the war ended or later, including four in the 1950s.

6 The Trade Mission functioned as socialist Yugoslavia's de facto embassy to the Federal Republic following the severing of official diplomatic ties between the countries in 1957 as a result of the Hallstein doctrine.

7 National Archives of Australia [Hereafter NAA]. Series A5034, Item 1973/2136 PART 1 "Croatian Terrorism: Relations with Yugoslav Government - Part I". Doc: "Croatian Extremist Activity in Australia".

${ }^{8}$ Politisches Archiv des Auswärtigen Amtes (Political Archives of the Foreign Office [of Germany], Hereafter PAAA). Bestand B42, Band 1475: Dok. 5. Mai 1972 "Besprechung mit dem Beauftragten für das Konsularwesen der jugoslawischen Regierung, E. Kljun, am 19. 4. 1972 um 10.30 Uhr über Aktivitäten kroatischer Emigrantenorganisationen”. 
militant foreign nation terrorist organizations operating in the United States (Kushner, 2003: 346).

Contemporary appraisals of Croat émigré political violence both inside socialist Yugoslavia and in the countries where Croat separatists were most active routinely and persistently branded anti-Yugoslav terrorism as the work of "Ustaša" elements in the emigration. In truth - the clear normative aim of this labeling aside, particularly from the side of the regime in Belgrade - the characterization of those engaging in violence to bring about the destruction of the Yugoslav state and establishment of an independent Croatia as being "Ustaša" obfuscated more than it revealed about the nature of émigré Croat separatist political violence. Unquestionably, wartime-era members of the Ustaša played an active and even central role in Croat émigré politics during the entirety of the Cold War. Anywhere from 30,000 to 50,000 members of the Ustaša escaped Partisan capture at the end of the war, finding refuge in countries such as Argentina, Uruguay, the United States, Australia and West Germany. ${ }^{9}$ Among those who managed to flee were some of the NDH's highest ranking ministers, officials and military officers, including Vjekoslav 'Maks' Luburić, Rafael Boban, Andrija Artuković, Vjekoslav Vrančić, Džaferbeg Kulenović, and none other than the Poglavnik himself, Ante Pavelić. ${ }^{10}$ Once settled abroad, Pavelić and his fellow Ustaše set about organizing a political opposition to the regime in Belgrade, including a government in exile in Buenos Aires and military formations called the Croatian Armed Forces (HOS - Hrvatske oružane snage) located around the globe.

Importantly, however, missing from post-war émigré Ustaša politics - the existence of the HOS notwithstanding - was a return to the political violence that had been an integral part of the inter-war Ustaša movement. Before being installed into power by the Axis Powers in 1941 and engaging in a brutal campaign of genocidal violence throughout the war, the Ustaša had been one of the most notorious terrorist organizations of the 1930s. Sponsored primarily by Mussolini's fascist Italy, the Ustaša committed a number of acts of political violence and terrorism aimed at hastening the downfall of the royalist Yugoslav government, the most infamous of which being the assassination of King Aleksandar in Marseilles on 9 October, 1934 together with members of the Internal Macedonian Revolutionary Organization (VMRO - Vnatrešna Makedonska Revolucionerna Organizacija). In the 1950s,

9 PAAA. Abteilung 7 [Bestand B12], Band 562, Dok. 684/56: "Die jugoslawische Emigration von 1914 bis zur Gegenwart, 1956" (20. Juni 1956), p. 65.

${ }^{10}$ Luburić was general commander of the notorious Jasenovac concentration camp. Boban had been commander of the Black Legion (Crna Legija). Artuković served as the NDH's Minister of the Interior and Minister of Justice and Religion. Vrančić had been Minister of Craftsmanship and Trade. Kulenović served in the position of Deputy Prime Minister. 
following the final 1948 defeat of the post-war domestic Križari guerilla campaign against the regime in Belgrade, ${ }^{11}$ Pavelić and other wartime Ustaše attempted to refashion themselves as democratically-leaning staunch anti-communist supporters of the struggle against the forces of state socialism in the hope of currying the favor of the Western Allies. ${ }^{12}$ The hope was that when the inevitable - and indeed welcome - conflict between East and West came - which would be followed by the equally inevitable victory of the West - the Croats' reward for their minor but nevertheless crucial contribution to the defeat of the East would be a country of their own. ${ }^{13}$

To be sure, Pavelić and his ilk rhetorically upheld terrorism and political violence as remaining central to their movement for Croatian independence. The NDH, they claimed, had come into existence due to the Ustaša inter-war campaign of violence that had given the movement both standing on the international stage and legitimacy as representatives of the nation. As such, both the history and promise of political violence remained at least discursively integral to the Ustaša political identity after the Second World War. Nevertheless, the reality of the post-war separatist movement was that political violence and terrorism had ceased to feature as part of the operational repertoire of exile Ustaše. A number of factors - chief among them ruinous discord within the exile community amongst competing factions in the 1950s - had the effect of making the overall movement for Croatian independence effectively impotent. Pavelić and the main rivals to his throne - most notably Branko Jelić and Maks Luburić - all espoused political violence and terrorism as fundamental to achieving national liberation from the clutches of "Serbo-communism". But at least through the 1950s and into the 1960s, the émigré separatist

11 The Križari were a group of Croat anti-Yugoslav guerillas made up primarily of Ustaša soldiers who continued to engage in violent acts against the new regime until as late as 1950 .

12 It should be noted that while the pursuit of allegiances with the Western Powers was preferred among émigré Croats, other options were considered. Following the Tito-Stalin split of 1948, émigré Croats like many others believed a Soviet invasion of Yugoslavia to be inevitable. In hopes of securing a new Croatian state, a faction of Argentina-based Ustaša exiles offered the Soviet Union assistance in the coming conflict in the form of a division of Ustaša soldiers who had fought during the Second World War. In exchange for their aid, the Ustaša asked only that Moscow establish a Croatian state from the remnants of a divided Yugoslavia. That this new state would be under direct Soviet hegemony was secondary to the very fact of its independence from Belgrade. Ultimately, such advances came to nothing. PAAA. Referat IIA5 [Bestand B42], Band 98, Dok. 1222/61: "Die kroatischen Exil - Ustaschen: Nationalistischer Extremismus und kommunistische Unterwanderung / Zum Stuttgarter Zwischenfall” (1. Dezember 1961), p. 5-6, and PAAA. Abteilung 7 [Bestand B12], Band 562, Dok. 1308/56: "Die Auseinandersetzungen im Ustaschen-Lager (Kroatische Emigration Juli-August 1956)" (14. September 1956), p. 6-7.

13 National Archives and Records Administration (Hereafter NARA). CIA. "Yugoslavia/Argentina, Ustasha Activity Abroad" (2 October 1951), p. 2. 
movement remained stagnant, with political violence existing only as a rhetorical exercise rather than actual political strategy.

The active re-embrace of terrorism and political violence within the émigré separatist movement came only with a new wave of Croatian emigrants moving to the West from Yugoslavia beginning in the late 1950s and early 1960s. In the decade between 1952 and 1962, unemployment in socialist Yugoslavia rose from 45,000 to nearly 240,000 (Zimmerman, 1987: 96; Woodward, 1995). Unsurprisingly, illegal emigration over the same time experienced a sharp increase, with one estimate putting the number at anywhere between 250,000 and 500,000 people (Mesić, 1991: 13). Croats comprised by far the greatest number of those who left Yugoslavia to seek better fortunes in the West, with Croats from both the republics of Croatia and Bosnia-Herzegovina comprising two-thirds of emigrants from Yugoslavia despite making up just over one-fifth of the country's population according to one survey looking at the first half of the 1960s (Savezni zavod za statistiku, 1971: 9). This tide of migration only increased with the liberalization of Yugoslavia's immigration policy in the early $1960 \mathrm{~s}$. The combination of unemployment in socialist Yugoslavia with a shortage of labor in West Germany during that country's post-war Wirtschaftswunder, or economic miracle, led to a steady expansion of opportunities for Yugoslavs to go abroad, culminating in Belgrade and Bonn signing a bilateral labor agreement in 1968. Again, Croats constituted the majority of the so-called guest-workers who sought employment in the Federal Republic of Germany, with estimates putting their number at around 400,000 of the 600,000 Yugoslavs living in West Germany by 1975 (Shonick, 2009).

By any measure, this second generation of emigrants was decidedly less political than that which had fled at the end of the war. Certainly, many of the young Croats who left their homeland in the hope of securing a better life in the West from the late 1950s onwards viewed the socialist regime in Yugoslavia critically, if not indeed acrimoniously. And even among those whose relationship with Belgrade was perhaps more ambiguous, there was generally widespread support - albeit often quite abstract - for national independence and the establishment of a Croatian state separate from Yugoslavia. Nevertheless, politics - and even less so separatism was rarely the primary motivating factor behind emigration out of the country. Once abroad - as is common in diaspora communities - political issues came to occupy a central place in the social lives of many younger emigrants. But for the vast majority, politics took a definitive backseat to concerns more directly related to their own well-being and that of their families who remained in Yugoslavia. To be sure, the older generation of post-war émigrés made every effort to recruit new arrivals into their ranks, using tactics ranging from assistance in procuring employment, housing, documentation and other necessities to blackmail, extortion and even physical 
intimidation. ${ }^{14}$ But more often than not, such overtures were eschewed, with younger emigrants simply wishing to build a new life abroad that was stable and secure.

Still, many among this new generation were of course deeply committed to the cause of Croatian independence, with not an insignificant percentage coming to view the use of political violence as an acceptable - if not indeed necessary means by which to advance the cause of national liberation. Importantly, however, the embrace of terrorism as political strategy was not the product of the spread of "Ustašism" from one generation to the next, as was claimed by the Yugoslav state and others at the time. On the contrary, the violent radicalization of younger emigrants developed in direct opposition to the older generation, the result of a deep and ardent disillusionment with the old guard. ${ }^{15}$ For all their posturing and bluster, extremist separatists among newer arrivals in the West felt the post-war generation of Ustaša émigrés had accomplished very little since the collapse of the NDH and the establishment of Tito's socialist Yugoslavia. Indeed, the thinking continued, the old guard of Ustaša had not just helped bring about the stagnation of émigré politics, but had in fact actively stifled any and all efforts to affect true revolutionary change in Croatia. ${ }^{16}$ Quite simply, young radicals came to feel, the older generation was not to be revered or emulated, but rather viewed with suspicion, distrust and even antipathy.

The main point of contention strategically between the two generations of emigrants revolved around the issue of the degree to which the fate of the Croatian nation should be placed in the hands of the Great Powers, particularly the United States. With an eye to the inter-war period - the Ustaša had risen to prominence through the patronage of Mussolini's Italy and, to a lesser extent, Horthy's Hungary, and had come to power thanks to the might of Hitler's Nazi Germany many older emigrants, including Ante Pavelić, viewed Great Power sponsorship as the only viable path to national liberation. ${ }^{17}$ After the Second World War, Pavelić and other émigré Ustaša put the weight of their efforts into lobbying the Western

14 PCA-Senate. Tabled Papers, 28 March 1973: "Croatian Extremists". Appendix B.15A, Doc: "Extract from Commonwealth Police Report of 20 October 1972 United Croats of West Germany"; PAAA. Referat IIA5 [Bestand B42], Band 999, Dok. 747/62: "Probleme der jugoslawischen Gastarbeiter" (9. Oktober 1962); and NARA. RG 59, Box 4151 (1963), Folder: Pol 25 Demonstrations, Protests, Riots (2/1/63), Doc: "Activities of the Ustashi Terrorist Organizations".

15 PCA-Senate. Tabled Papers, 27 March 1973: "Croatian Extremists". Appendix A.5/D, Doc: "Croatian Revolutionary Brotherhood Committee Area No. 4: Letter from Supreme Headquarters to Revolutionaries in this Committee Area" (15 July 1964).

16 PCA-Senate. Tabled Papers, 28 March 1973: "Croatian Extremists". Appendix B.18, Doc: Exhibit 30, "Cr(oatian) Rev(olution) and Its Preparations", p. 4.

17 NARA. CIA. "Yugoslavia/Argentina, Ustasha Activity Abroad" (2 October 1951), p. 2. 
Powers firstly for recognition of their cause and secondly for assurances that the Croat nation would not be forgotten during the inevitable political reorganization of southeastern Europe that would occur following the unavoidable conflict between East and West that loomed on the horizon. Along these lines, during the Korean War Ante Pavelić offered an entire legion of Croatian soldiers to the United Nations in support of that body's war effort against the Chinese and North Korean communists. ${ }^{18}$ Similarly, in 1957, Pavelić pledged to the leadership of NATO in Brussels the support of the Croatian diaspora in the form of a military legion of former Ustaša solders in the advent of a war against the forces of communism. ${ }^{19}$ More mundanely, former Ustaša émigrés barraged officials in Washington, London, Bonn, and elsewhere with letters, treatises and memoranda outlining the oppressive nature of the regime in socialist Yugoslavia and calling for immediate and forceful intervention by the West to end "Serbo-communist" tyranny over the freedom-loving peoples of Croatia.

The more radical of the second generation of post-war separatists - including those who belonged to the HRB and participated in operation Feniks - viewed such a strategy as not just futile but indeed ruinous for Croatia and the Croat nation. On the former point - the futility of relying on Great Power patronage - younger antiYugoslavs argued that global politics in the Cold War bore little resemblance to the politics of the inter-war period and therefore could not serve as a model..$^{20}$ The constellation of interests among those states in a position to support the political aims of the Ustaša in the lead-up to the Second World War favored Ante Pavelić and his followers, although even this was tested following the assassination of King Aleksandar. When War did descend on the Balkans in 1941, the Ustaša movement was a known quantity in the capitals of the Axis Powers - particularly in Rome - who saw it to their advantage to dismember royalist Yugoslavia in the pursuit of their own strategic aims. Famously, Pavelić was not the man first approached to lead the independent Croatian state - the head of the Croatian Peasant Party (HSS - Hrvatska seljačka stranka) Vladko Maček twice refused the offer to assume the position ${ }^{21}$ but was nevertheless number two on the list and gladly jumped at the opportunity to assume authority over the new state.

\footnotetext{
18 Ibid.

19 PAAA. Abteilung 7 [Bestand B12], Band 562, Dok: "Letter from the HOP to the signatories of NATO" (December 1957).

${ }^{20}$ PCA-Senate. Tabled Papers, 28 March 1973: "Croatian Extremists". Appendix B.18, Doc: Exhibit 30, "Cr(oatian) Rev(olution) and Its Preparations", p. 3-4.

${ }^{21}$ Maček did, however, instruct the members of his party - by far the largest, most popular and most powerful in Croatia - to support the regime of Ante Pavelić.
} 
During the early years of the Cold War, many observers of global politics - not just émigré Croats - were convinced that a direct military conflict between the United States and the Soviet Union was inevitable, a belief, as mentioned, that shaped post-war Croatian separatist strategy throughout the 1950s. By the early 1960s, however, the growing détente between Washington and Moscow made it clear at least to the younger generation of separatists that exclusively pursuing Great Power patronage in the hope of reaping the benefits of being on the "right side" of World War III was akin to waiting on a ship that would never sail. This was coupled with a somewhat more nuanced understanding of world politics than that held by the older generation. The second wave of Croat emigrants recognized that the destruction of socialist Yugoslavia - which naturally was a precondition for the establishment of an independent Croatia - was not even in the interests of the Western Bloc. ${ }^{22}$ One consequence of the Tito-Stalin split in 1948, younger émigrés understood, was that the United States was heavily invested in the maintenance of Tito's state both politically and territorially (Banac, 1988; Perović, 2007). A stable, unified, West-friendly socialist Yugoslavia, Washington believed, would serve as a bulwark against possible Soviet expansion towards the Mediterranean, and in particular create a buffer shielding Greece, a crucial but precarious Western ally. As such, younger Croat emigrants came to believe, even if war did come between the forces of communism and democracy, there was no guarantee that the post-war restructuring of Europe's political landscape would favor the Croats even in the event of a Western victory.

More crucially, meanwhile, the strategy employed by the older generation of simply waiting for a Great Power confrontation to create the necessary conditions for national liberation - according to younger radicals - appeared willfully oblivious to the very real existential threat faced by the Croat nation within socialist $\mathrm{Yu}$ goslavia. For politicized Croat emigrants of all generations, there was no question that "Serbo-communist" rule in Yugoslavia was manifestly tyrannical, oppressive and brutally discriminatory against Croats. But for hardline separatists who had gone abroad in the late 1950 s and early 1960 s, the issue was not simply one of authoritarianism and repression. Rather, they viewed the regime in Belgrade as actively pursuing nothing less than - to use their words - the "biological destruction" of the Croat nation. ${ }^{23}$ From their perspective, the policies enacted by the Yugoslav government were deliberately aimed at progressively and inexorably obliterating Croatian national identity and by extension the nation itself. This was done through

22 PCA-Senate. Tabled Papers, 28 March 1973: "Croatian Extremists". Appendix B.18, Doc: Exhibit 000132, p. 1.

23 Archives of New Zealand [Hereafter ANZ]. ABHS, 950, Acc W4627. Box 4123, 275/2/1, Part

6. Doc: "The Canadian Croatian Federation", p. 1. 
a combination of tactics including mass incarcerations and even executions, the artificial induction of economic crises in the republic, the dismantling of national cultural and political institutions, the organized promotion of emigration out of the country, and the wholesale plunder of the nation's economic resources and potential. ${ }^{24}$ Thus, the conclusion was that, together, these policies comprised a concerted and clear effort by the regime in Belgrade to promote a pan-Serbian ideology that would result in the establishment of a Greater Serbian Yugoslav state whose existence was predicated on the elimination of the Croat nation through a program that could be characterized as nothing other than genocide. Even more, hardline separatist communities took Đilas' citation in Avengers of Bleiburg as evidence that genocide against the Croat nation was embedded in the very DNA of Tito's socialist Yugoslavia, going back to the inception of the state itself. By this was meant the massacre at Bleiburg, which not only created the conditions by which the existence of the state was possible but stipulated the conditions necessary for the state's survival, namely the actual physical extermination of the Croats.

For centuries, radical separatists declared, the Croats had endured the indignities and injustices brought on by foreign domination, be it by the Austrians, the Hungarians, the Turks, the Italians, or the Serbs. But in the nearly nine centuries since the Croat nation had lost its independence, nothing compared to the calculated, systematic and deliberate genocide wrought by the Serbo-communists at Bleiburg and subsequent Way of the Cross (Križni put). However much desired by Tito and his Partisan accomplices, the destruction of the Croat nation could obviously not be accomplished at one fell swoop. But Bleiburg afforded the opportunity to eliminate both the most ideologically dedicated and the most militarily experienced adherents to the principle of Croatian state rights. With these groups out of the way, the gradual demographic destruction of the Croat nation through ruinous land reform, purposefully engineered unemployment, systematic internments, pressure to migrate abroad and countless other measures would prove that much more straightforward to realize.

Largely, this view of the events of Bleiburg conformed to those held generally among politicized Croat emigrants (Prpic, 1973; Beljo, 1985). Following the Second World War, the history and memory of Bleiburg formed the core of an emergent victim identity within the global Croat community not dissimilar to the 1915 genocide for Armenians, Katyn for Poles, Operation Bluestar for Sikhs, and the destruction of the Temple of Solomon and, much more recently, the Holocaust for Jews (Cohen, 1996). In many ways, Bleiburg served as the nucleus for the development of a true Croat 'diaspora', providing a potent memory narrative around 
which, on the one hand, calls for ethnonational unity could be mobilized and, on the other, ethnonational catharsis for the 'missteps' of the past - ranging from the union with Hungary in 1102 to the 'misguided' allegiance with Nazi Germany during the Second World War - could occur. This latter point was particularly important as Bleiburg mitigated - if not in fact removed - any sense of collective guilt Croats might be compelled to feel for the many crimes committed in their name during the reign of Ante Pavelić in the Second World War (Beljo, 1985: 43). In a world comprised of simple binaries, Bleiburg ensured that the Croat nation moved from "perpetrator" to "victim", from "oppressor" to "oppressed" and indeed from "sinful" to "absolved" (MacDonald, 2002; Kolstø, 2010). The undeniable "fact" of Bleiburg translated into unassailable "facts" about both the Croat national character and the regime in Belgrade, all of which operated in incontrovertible dichotomies with no room for complexity, nuance or even debate.

What slightly differentiated the radical emigrant separatist rhetoric regarding Bleiburg from that of the larger diaspora community is that Bleiburg was treated less as 'event' than as 'practice', much as Auschwitz for the Jews or Jasenovac for the Serbs represent much more than simply 'places' within their respective identity discourses. As long as socialist Yugoslavia continued to exist, extremist members of the younger generation of post-war emigrants reiterated persistently, Bleiburg remained as much a threat looming over the future of the Croat nation as a tragic episode residing in the nation's past. For this reason, there could be no delay in bringing about the destruction of Tito's "criminal state". Furthermore, for the younger radicals, the waiting game played by the older generation of post-war émigrés played directly into the hands of the regime in Belgrade, which was happy to pursue a policy of genocide through attrition as much as by way of massacre, as they had done at Bleiburg. In this way, the younger generation boldly declared in no uncertain terms, older Ustaša émigrés - through their incompetence, impotence and indeed duplicity - were in fact at least partially complicit in Serbo-communist efforts to bring about the biological destruction of the Croat nation. ${ }^{25}$

Significantly - and notably - no small measure of the younger generation's audit of the many transgressions of their forebears focused on the latter's culpability for the national tragedy that occurred at Bleiburg. ${ }^{26}$ An historical reckoning of the events that led up to those fateful days in May 1945, younger radicals asserted, showed that the catastrophe that befell those hundreds of thousands of innocent

${ }^{25}$ PCA-Senate. Tabled Papers, 28 March 1973: "Croatian Extremists”. Appendix B.18, Doc: Exhibit 000131, "Dedication", p. 4.

${ }^{26}$ Library and Archives of Canada [Hereafter LAC]. RG 25, Vol. 9360, File 20-18-1-5, Part 5, Doc: "Foreign Language Press Review Service; Summary of material from Hrvatski Glas" (Winnipeg, May 13, 1970), p. 1. 
men, women and children was entirely avoidable. There was simply no reason for the victims of Bleiburg to have been in the position at all to fall into the hands of the vengeful and murderous forces of Tito's Partisans. ${ }^{27}$ In the most generous scenario, younger radicals contended, the fact that so many innocent people had been left as exposed and vulnerable as they were came down to the utter and complete ineptitude of the national leadership at the end of the war. Far less charitably, some members of this second generation of post-war emigrants charged the political and military establishment of the NDH of consciously and willfully sacrificing "countless innocent Croat lives" in order to facilitate their own escape from advancing Partisan forces. Either way, there could be no denying that it was highly suspicious that so many high-ranking officials within the Ustaša managed to avoid capture while so many noncombatants and ordinary Croatian foot soldiers met such a tragic end. At the very least, this fact required the nature of the actions of the NDH's elite at the end of the war to be called into question.

At a minimum, the Bleiburg tragedy meant that the remnants of the NDH in the emigration no longer possessed either the political or moral authority to continue in its role as self-appointed vanguard of the struggle for national liberation. To be sure, the second generation of post-war emigrants still lauded the Ustaša movement not only for its actions in the inter-war period but also for having loyally and unwaveringly pursued the interests of the Croat nation during the war. ${ }^{28}$ Censure of the actions of the leadership of the Ustaša in May 1945 by younger radical separatists was in no way equated with criticism of - or even a distancing from - the genocidal policies pursued by the regime of Ante Pavelić Ustaša. Rather, the point was that beginning with Bleiburg the older generation had started along a path that, if followed, would lead to certain disaster for the nation. ${ }^{29}$ Two decades of abject failure by those Ustaša in the emigration to affect any change in socialist Yugoslavia since the Second World War, together with the regime in Belgrade growing only more legitimate in the eyes of the Western powers and more bold in its persecution of the Croats brought this reality into sharp relief. The old guard had had its time, and even had brought glory to the Croat nation. But the inefficacy and indeed ineptitude of the older generation was now only setting the cause of national liberation back. Worse, the inability and even unwillingness to act was a facilitating factor in the ongoing "Serbo-communist" efforts to bring about the biological destruction

27 Ibid.

28 PCA-Senate. Tabled Papers, 27 March 1973: "Croatian Extremists". Appendix A.5/D, Doc: "Croatian Revolutionary Brotherhood Committee Area No. 4: Letter from Supreme Headquarters to Revolutionaries in this Committee Area" (15 July 1964), p. 1.

29 PCA-Senate. Tabled Papers, 28 March 1973: "Croatian Extremists". Appendix B.18, Doc: Exhibit 000131, “Dedication”, p. 4. 
of the Croat nation. For this to change, the true mantel of revolutionary struggle against the regime in Belgrade that the older generation had dropped in the fields of Bleiburg at war's end had to be taken up by a whole new generation.

The result was the formation in the early 1960s of groups such as the Croatian Revolutionary Brotherhood, the Croatian Crusaders Brotherhood, the Secret Revolutionary Ustaša Command (TRUP - Tajna revolucionarna ustaška postrojba), the Australo-Croatian National Resistance (AHNO - Australsko-hrvatski narodni odpor), and numerous other organizations that were comprised either wholly or in large part by members not of the immediate post-war emigration, but those who emigrated a generation later. Based in cities as far spread as Sydney, Stockholm and San Pedro, California, these organizations all were founded on the steadfast belief that the youth and the youth alone - i.e. the "modern Croatian revolutionaries" referenced by Andrić in Avengers of Bleiburg - could deliver the Croat nation from the clutches of "Serbo-communist" oppression and genocide. ${ }^{30}$ The members of these organizations also all believed that the only way to realize the centuries-old dream of the Croat nation to establish a truly sustainable independent state was through violent revolutionary struggle. ${ }^{31}$ And in the face of the overwhelming might of the Yugoslav People's Army (JNA - Jugoslavenska narodna armija), the opening salvo in that revolutionary struggle had to take the form of terrorism and guerilla action amongst those fortunate enough to be living in the emigration. ${ }^{32}$ Channeling the nineteenth-century notion of "propaganda of the deed", young radical separatists viewed acts of terrorism and political violence as being not just a legitimate but indeed necessary way to both lay the foundation and serve as the inspiration for the eventual development of the decisive revolutionary movement amongst Croats within socialist Yugoslavia that would lead to independence. ${ }^{33}$

One such action was Operacija Feniks, which, as the name implies, was to be the moment the Croat nation experienced its rebirth and renewal out of the ashes of the fiery cauldron of despair wrought by the regime in Belgrade. Of course, as mentioned, the operation failed to herald in a new revolutionary moment for Croatia and the Croats. But neither was Feniks insignificant or inconsequential, just as the

30 PCA-Senate. Tabled Papers, 27 March 1973: "Croatian Extremists". Appendix A.5/D, Doc: "Croatian Revolutionary Brotherhood Committee Area No. 4: Letter from Supreme Headquarters to Revolutionaries in this Committee Area" (15 July 1964), p. 1-2.

31 PCA-Senate. Tabled Papers, 28 March 1973: "Croatian Extremists". Appendix B.18, Doc: Exhibit 30, “Cr(oatian) Rev(olution) and Its Preparations", p. 1-2.

32 PCA-Senate. Tabled Papers, 27 March 1973: "Croatian Extremists". Appendix A.5/F, Doc: "REVOLUTION".

33 NAA. Series A432/15, Control Symbol 1963/2357, Part 3, Item 1111184, Doc: Exhibit 000104: Letter from Geza Pašti to Jure Marić (2 August 1964), p. 1-3. 
scores of other acts of terrorism and political violence perpetrated by young extremist separatists in emigration in the decade preceding and the decade following the incursion in and around Bugojno were far from being trivial or otherwise without impact. In addition to the acts of the HRB mentioned in the opening paragraph of the chapter, radical Croats detonated dozens of bombs targeting institutions of the Yugoslav state - such as at embassies, travel offices and passenger trains - in major cities around the world, successfully assassinated several officials of the Yugoslav regime in countries such as West Germany and Sweden, and executed two high profile hijackings of airplanes over a twenty year period. True, none of these acts hastened either the collapse of socialist Yugoslavia or the establishment of an independent Croatia. But they all resonated with different degrees of intensity not just among both the leadership and population in Yugoslavia itself, but indeed globally.

And in many ways, each act of violence had at least some connection to the memory of Bleiburg, although rarely as simply as an action taken to "avenge" the massacre, as the title of Andrić's manual suggested. Bleiburg stood at the nexus of a complex constellation of generational dynamics, personal power struggles, memory politics and discursive disputes, much as rhetoric surrounding the events of May 1945 do today in Croatia. And much like today, these conflicts within the radical emigrant separatist movement regarding Bleiburg often had very little to do with the massacre itself, but instead served as a powerful symbolic platform to promote certain political or strategic agendas and to vilify - or at the very least marginalize - others. Within the milieu of radical emigrant separatism, Bleiburg served two crucial roles, both of which proved formative into making Croatian terrorism such an active force - if perhaps somewhat ineffectual - in not just Yugoslav but indeed world politics. The first - ethnonational mobilization around a potent victim rhetoric - occupies a tried and true place in not just the identity politics of diaspora communities, but indeed of communities of all kinds. The second is less obvious but perhaps more noteworthy, namely the centrality of the competition amongst different generational factions of radical emigrants regarding the manner in which Bleiburg should be treated historically in the radicalization of Cold War era Croatian separatism. Bleiburg was perhaps not, as the expression goes, either a sufficient or necessary condition for the development of post-Second World War anti-Yugoslav Croatian political violence and terrorism. But the emergence, evolution, spread and appeal of the forces behind that violence were very much shaped by Bleiburg, the consequences of which reached far and wide. 


\section{REFERENCES}

Apostol Plemić [Adolf Andrić]. 1974. Osvetnici Bleiburga: "Priručnik” za vođenje Hrvatske gerile. Drugo izdanje. Osvetnici Bugojna.

Bayo y Giroud, Alberto. 1963. 150 Questions for a Guerilla. Denver, CO: Panther Publications.

Banac, Ivo. 1988. With Stalin against Tito: Cominformist Splits in Yugoslav Communism. Ithaca, NY: Cornell University Press.

Beljo, Ante. 1985. Jugoslavija Genocid: dokumentarna analiza. Sudbury, Canada: Northern Tribune Publishing.

Borne, Eric. 1972. "Tensions in Yugoslavia”. The Christian Science Monitor (August 2).

Clarkson, Alexander. 2013. Fragmented Fatherland. New York: Berghahn.

Clissold, Stephen. 1979. "Croat Separatism: Nationalism, Dissidence and Terrorism". Conflict Studies, no. 103 (January): 1-21.

Cohen, Robin. 1996. "Diasporas and the Nation-State: From Victims to Challengers". International Affairs, vol. 72, no. 3 (July): 507-520.

Irvine, Jill. 2008. "The Croatian Spring and the Dissolution of Yugoslavia", in: Lenard J. Cohen and Jasna Dragović-Soso (eds.): State collapse in South-Eastern Europe: new perspectives on Yugoslavia's disintegration. West Lafayette, IN: Purdue University Press: 149-178.

Kolstø, Pål. 2010. "Bleiburg: The Creation of a National Martyrology". Europe-Asia Studies, vol. 62, no. 7 (September): 1153-1174.

Kushner, Harvey W. 2003. Encyclopedia of Terrorism. Thousand Oaks, CA: Sage Publications.

MacDonald, David Bruce. 2002. Balkan Holocausts? Serbian and Croatian Victim-Centered Propaganda and the War in Yugoslavia. Manchester: Manchester University Press.

Mesić, Milan. 1991. Vanjske migracije i društveni razvitak. Zagreb: Institut za migracije i narodnosti Sveučilišta u Zagrebu.

Perović, Jeronim. 2007. "The Tito-Stalin Split: A Reassessment in Light of New Evidence". Journal of Cold War Studies, vol. 9, no. 2 (Spring): 32-63.

Prpic, George J. 1973. Tragedies and Migrations in Croatian History. Toronto: Hrvatski Put.

Savezni zavod za statistiku. 1971. "Lica na privremenom radu u inostranstvu: prema popisu stanovništva i stanova 1971”. Statistički Bilten, no. 679.

Shonick, Kaja. 2009. "Politics, Culture, and Economics: Reassessing the West German Guest Worker Agreement with Yugoslavia". Journal of Contemporary History, vol. 44, no. 4 (October): 719-736. 
Woodward, Susan L. 1995. Socialist Unemployment: The Political Economy of Socialist Yugoslavia, 1945-1991. Princeton, NJ: Princeton University Press.

"Yugoslavia - The Ustashi and the Croatian Separatist Problem, 27 September, 1972". 2007. In: From "National Communism" to National Collapse: U.S. Intelligence Community Estimative Products on Yugoslavia, 1948-1990. Washington, D.C.: GPO.

Zimmerman, William. 1987. Open Borders, Nonalignment, and the Political Evolution of Yugoslavia. Princeton, NJ: Princeton University Press.

Mate Nikola Tokić is Visiting Professor at Department of International Relations, Central European University.

Mailing Address: Mate Nikola Tokić, Department of International Relations, Central European University, Akademia u. 1, Budapest, 1051, Hungary.

E-mail:TokicM@ceu.hu 